\title{
Rice-Rape Rotation Benefits to Improve Radiation and Heat Use Efficiencies and Mitigate Global Warming Potential of Paddy Cropping Systems in Central China
}

\author{
Gong Songling ${ }^{1,2}$, Li Chengwei ${ }^{1,2}$, Zhou Yong ${ }^{1,2}$, Yan Xiaoyuan ${ }^{1,2}$, Zhu Rong ${ }^{1,2}$, Zhu Bo ${ }^{1,2^{*}}$ and Liu Zhangyong ${ }^{1,2}$ \\ ${ }^{1}$ Hubei Collaborative Innovation Centre for Grain Industry, College of Agriculture, Yangtze University, Jingzhou, 434025, P. \\ R. China \\ ${ }^{2}$ Engineering Research Center of Ecology and Agricultural Use of Wetland, Ministry of Education, Yangtze University, \\ Jingzhou, 434025, P. R. China \\ "For correspondence: 1984zhubo@163.com \\ Received 22 January 2021; Accepted 25 February 2021; Published 10 May 2021
}

\begin{abstract}
Replacing bare fallow by rotation with winter cereal crops such as winter wheat and oil rape have been used to improve annual productivity in paddy cropping system in central China. However, the effects of rotation on light and heat resources utilization and greenhouse gases have yet to be measured. A two-year field experiment was conducted to compare solar radiation and heat use efficiencies, methane $\left(\mathrm{CH}_{4}\right)$ and nitrous oxide $\left(\mathrm{N}_{2} \mathrm{O}\right)$ emissions and global warming potential (GWP) of two winter rotations: rice-wheat and rice-rape taking rice-fallow as a check. The results of this study showed that rice-wheat had the highest annual grain yield (two-year means were $\left.16.2 \mathrm{t} \mathrm{ha}^{-1}\right)$ and annual above ground biomass $\left(32.9 \mathrm{t} \mathrm{ha}^{-1}\right)$ followed by ricerape and by rice-fallow. No significant effect was observed for winter rotation on the performance of rice grain yield and growth, in spite of a large quantity of straw returning by winter crops. Solar radiation and heat resources utilization and their production efficiency were improved in the winter season by rotation with winter crops. Rice-wheat and rice-rape also increased light and heat resources utilization efficiency from the annual perspective. Compared with rice-fallow, $\mathrm{CH}_{4}$ flux in the rice season among the two studying years was increased by $42.0 \%$ by rice-wheat but was decreased by $35.6 \%$ by rice-rape. For the annual level, $\mathrm{CH}_{4}$ flux was promoted by $40.9 \%$ by rice-wheat and declined by $35.5 \%$ by rice-rape. For the rice season the $\mathrm{N}_{2} \mathrm{O}$ seasonal flux was increased by 54.2 and by $8.3 \%$ in rice-wheat and rice-rape plots, respectively. The values for GWP and for yield-scaled GWP were highest in rice-wheat and lowest in rice-rape system. In conclusion, rice-rape system could be a better choice to increase solar radiation and heat resources utilization and mitigate greenhouse gases emission. (C) 2021 Friends Science Publishers
\end{abstract}

Keywords: Sustainability; Paddy cropping system; Rotation; Greenhouse gases; Central China

\section{Introduction}

Agriculture development is now facing a worldwide concern for sustainability mostly in three aspects: 1) food supply for an increasing population; 2) improving resources utilization efficiency and 3) mitigating detrimental items emission into the environment such as greenhouse gases (GHG). As one of the most important staple food, rice (Oryza sativa L.) feeds more than $50 \%$ of the world's population (Zhou and Sun 2017). According to FAO (2019), China accounts for approximately $28 \%$ of the global rice production and $18 \%$ of the world's planting area. Food supply, resources utilization and environmental issues in paddy ecosystems, especially in central and south China are getting more and more concerns.

Previous research has confirmed that rotation in paddy cropping systems, especially those with legumes could play an important role in promoting nutrient cycling, improving soil fertility and maintaining food production by reducing fertilizer investment (Nie et al. 2019). The release of environmental hazard compounds such as $\mathrm{NO}_{3}^{-}$leaching and $\mathrm{N}_{2} \mathrm{O}$ emission from farmland could also be reduced by rotation ( $\mathrm{Yu}$ et al. 2014; Machado et al. 2021), or by replacing winter fallow with cover crops (Zhu et al. 2016). Fewer $\mathrm{N}$ losses were observed from crop residues than from chemical fertilizers when residues were incorporated into the soil in different rotation systems (Congreves et al. 2017; Taveira et al. 2020).

Studies on agricultural resources utilization have been focused on artificial nonrenewable resource inputs such as nitrogen fertilizer (Liu and Zhang 2011), irrigation water (Jia et al. 2020), etc. The local non-renewable climate resources including solar radiation and heat are usually evaluated for single season crop production (Du et al. 2019). The analysis of cropping effects on solar radiation and

To cite this paper: Songling G, L Chengwei, Z Yong, Y Xiaoyuan, Z Rong, Z Bo, L Zhangyong (2021). Rice-rape rotation benefits to improve radiation and heat use efficiencies and mitigate global warming potential of paddy cropping systems in central China. Intl J Agric Biol 25:1231-1237 
cumulative temperature use efficiency from an annual perspective are quite few but in urgent need. As reported by Zhang et al. (2013), food production potential of paddy ecosystems in central China has been increased greatly in the past decades because of an increasing air temperature. The most popular paddy cropping system in central China is single rice followed by winter fallow or rotated with a winter crop such as winter wheat (Triticum aestivum L.) and oil rape (Brassica campestris L.). Therefore, the effects of rotation on radiation and accumulative temperature use efficiency need to be clarified to make a better use of resource potential.

Agriculture is considered as a major anthropogenic source of $\mathrm{CH}_{4}$ and $\mathrm{N}_{2} \mathrm{O}$, accounting for 50 and $60 \%$ of total $\mathrm{CH}_{4}$ and $\mathrm{N}_{2} \mathrm{O}$ emissions, respectively (Smith et al. 2007). About $30 \%$ of agricultural $\mathrm{CH}_{4}$ and $11 \%$ of $\mathrm{N}_{2} \mathrm{O}$ emissions released to the atmosphere are generated from rice paddies over the world (Mer and Roger 2001). Compared with fallow, rotation with cereals such as wheat, or with a winter cover may have profound effects on $\mathrm{CH}_{4}$ and $\mathrm{N}_{2} \mathrm{O}$ emissions from paddy field by altering organic or inorganic fertilizers application (Tellez-Rio et al. 2017) and complex soil conditions (Kamp et al. 2001). The effects of rotation on $\mathrm{CH}_{4}$ and $\mathrm{N}_{2} \mathrm{O}$ emissions from paddy soils are yet to be measured to make a more sustainable rice production.

Rotation with winter crops has been recognized as effective to promote nutrient cycling and reduce $\mathrm{N}_{2} \mathrm{O}$ emission from paddy fields (Yu et al. 2014; Zhu et al. 2016). However, the effects of winter crops rotation on radiation and heat use efficiencies, and global warming potential of paddy systems are not well reported. Therefore, this twoyear field study was designed with the hypothesis that winter rotations can improve resource use efficiencies and mitigate GHG emissions compared with winter fallow in paddy systems of central China.

\section{Materials and Methods}

\section{Site description}

The field experiment (2017-2019) was conducted in a farmer's field in Jiangling County $\left(30^{\circ} 12^{\prime} \mathrm{N}, 112^{\circ} 31^{\prime} \mathrm{E}\right)$, Hubei province, central China. This region is in the middle reaches of Yangtze River, one of the most important rice planting areas in China. The climate is humid and midsubtropical monsoon with an average temperature ranged from 16.0 to $16.4^{\circ} \mathrm{C}$ and an annual rainfall of $900-1100 \mathrm{~mm}$. The soil is fluvo-aquic, and before the start of the experiment the soil fertility was: $26.44 \mathrm{~g} \mathrm{~kg}^{-1}$ total carbon, $2.44 \mathrm{~g} \mathrm{~kg}^{-1}$ total nitrogen, $170.9 \mathrm{mg} \mathrm{kg}^{-1}$ alkaline hydrolyzed nitrogen, $0.38 \mathrm{~g} \mathrm{~kg}^{-1}$ total phosphorus, $12.7 \mathrm{mg} \mathrm{kg}^{-1}$ Olsen extractable phosphorus, $159.0 \mathrm{mg} \mathrm{kg}^{-1}$ available potassium, and $\mathrm{pH}\left(\mathrm{H}_{2} \mathrm{O}\right) 6.9$.

\section{Treatments and agronomic details}

The study was started at October 28 in 2016, before that the cropping system in the experimental field was one season rice followed by winter fallow for more than 10 years. In this study three rice cropping systems were compared: ricewinter fallow $(\mathrm{RF})$, rice-winter wheat $(\mathrm{RW})$ and rice-rape (RR). The treatments were arranged in a completely randomized block design with three replications. Nine plots of $98 \mathrm{~m}^{2}(14 \mathrm{~m} \times 7 \mathrm{~m})$ per individual plot were used. Plots were separated by $0.5 \mathrm{~m}$ wide ridges covered with plastic film to avoid water and nutrients runoffs.

Winter crops were transplanted or hand broadcast after rice harvest and straw incorporation by a rotary tiller in late October. For RR plots, rape seedlings ( $c v$. Huayouza62, 30d) were transplanted at a density of $30 \mathrm{~cm} \times 30 \mathrm{~cm}$ with a single seedling per hill. Wheat (cv. Zhengmai9023) seeds were hand broadcast at a rate of $225 \mathrm{~kg} \mathrm{ha}^{-1}$ in RW plots. The rape and wheat received the same base fertilizer application: $96 \mathrm{~kg} \mathrm{~N} \mathrm{ha}^{-1}, 60 \mathrm{~kg} \mathrm{P}_{2} \mathrm{O}_{5} \mathrm{ha}^{-1}$ and $132 \mathrm{~kg} \mathrm{~K}_{2} \mathrm{O}$ $\mathrm{ha}^{-1}$ (16:10:22\% compound fertilizer). The rape was applied with twice top dressings as $36 \mathrm{~kg} \mathrm{~N} \mathrm{ha}^{-1}$ (urea) and $7.5 \mathrm{~kg} \mathrm{~B}$ $\mathrm{ha}^{-1}\left(\mathrm{Na}_{2} \mathrm{~B}_{4} \mathrm{O}_{7} \cdot 10 \mathrm{H}_{2} \mathrm{O}\right)$ each time while the wheat was top dressed with urea at a rate of $45 \mathrm{~kg} \mathrm{~N} \mathrm{ha}^{-1}$. RF plots were kept fallow during the whole winter season. In early June, after winter crops harvest and soil management, rice seedlings (cv. Longliangyouhuazhan, 30d) were transplanted at a spacing of $26 \mathrm{~cm} \times 16 \mathrm{~cm}$ with 3 plants per hill. Rice plants received a fertilizer application in the form of $225 \mathrm{~kg} \mathrm{~N} \mathrm{ha}{ }^{-1}$ (urea), $75 \mathrm{~kg}_{2} \mathrm{P}_{2} \mathrm{O}_{5} \mathrm{ha}^{-1}$ (calcium superphosphate), and $180 \mathrm{~kg} \mathrm{~K}_{2} \mathrm{O} \mathrm{ha}^{-1}$ (potassium chloride). The fertilizer distribution was $40 \% \mathrm{~N}, 100 \% \mathrm{P}_{2} \mathrm{O}_{5}$ and $50 \%$ $\mathrm{K}_{2} \mathrm{O}$ for base fertilizers; $30 \% \mathrm{~N}$ for topdressing at tillering stage; $30 \% \mathrm{~N}$ and $50 \% \mathrm{~K}_{2} \mathrm{O}$ for the second topdressing at grain filling stage. The rice field was flooded by a $3-5 \mathrm{~cm}$ depth of water except for the mid-season drainage.

At maturity, grain yield of each crop was measured by randomly selected two $4 \mathrm{~m}^{2}$ areas for each plot. The aboveground biomass was separated into straw and grains and measured after oven drying at $75^{\circ} \mathrm{C}$ to constant weight.

\section{$\mathrm{CH}_{4}$ and $\mathrm{N}_{2} \mathrm{O}$ flux measurements}

$\mathrm{CH}_{4}$ and $\mathrm{N}_{2} \mathrm{O}$ fluxes were measured from June 2017 to May 2019, by using a closed chamber/gas chromatography method (Sun et al. 2018). The closed chamber (45 cm $\times 45$ $\mathrm{cm} \times 100 \mathrm{~cm}$ ) was put into the groove of a base which was fixed into the soil in each plot. Thereafter, water was filled into the groove to seal the chamber so no gas leaking will happen between the chamber and the covered field. A battery-driven fan was used to mix the air inside the chamber. For each flux measurement, three gas samples intervals were collected from 9:00 to 11:00 am by using a $25-\mathrm{mL}$ syringe at 0,8 and $16 \mathrm{~min}$ respectively, after the chamber was placed on the fixed base. The chamber was removed from its base after each gas sampling event. Gas samples were taken at 10-15 d intervals during the winter season and at 7-10 d intervals in the rice season.

$\mathrm{CH}_{4}$ and $\mathrm{N}_{2} \mathrm{O}$ concentrations were determined by 
using a gas chromatograph (Agilent 7890B, CA, USA) equipped with a hydrogen flame ionization detector (FID) and an electron capture detector (ECD). The oven and FID were operated at 50 and $300^{\circ} \mathrm{C}$, respectively. The temperatures for the column and ECD detector were maintained at 40 and $300^{\circ} \mathrm{C}$, respectively.

\section{Calculations for resource use efficiency and GHG emissions}

The $\mathrm{CH}_{4}$ and $\mathrm{N}_{2} \mathrm{O}$ fluxes $\left(F_{i}\right)$ were calculated based on the changes of concentration $(\Delta C)$ over the time duration $(\Delta t)$ (Mosier et al. 2006). Cumulative $\mathrm{CH}_{4}$ and $\mathrm{N}_{2} \mathrm{O}$ emissions $\left(C E_{i}\right)$ were calculated via the trapezoidal integration of the mean flux over sampling intervals (Mosier et al. 2006).

$$
\begin{aligned}
F_{i} & =\rho \times(V / A) \times(\Delta C / \Delta t) \times 273 /(273+T) \\
C E_{\mathrm{i}} & =\sum_{i=1}^{n}(F i \times \mathrm{D} i \times 24)
\end{aligned}
$$

Where $\rho$ is the density of $\mathrm{CH}_{4}$ or $\mathrm{N}_{2} \mathrm{O}, V$ is the volume of the chamber above the enclosed soil with the area of $A$. T is the temperature inside the chamber $\left({ }^{\circ} \mathrm{C}\right) . D_{i}$ is the interval in days of the adjacent two sampling events and 24 are the hours in a day.

Based on a 100-year time frame, the GWP coefficient is 25 for $\mathrm{CH}_{4}$ and 298 for $\mathrm{N}_{2} \mathrm{O}$ to $\mathrm{CO}_{2}$ equivalent (IPCC 2007). We calculated the combined GWP for 100 years using Eq. (3):

$$
G W P=25 \times C E\left(\mathrm{CH}_{4}\right)+298 \times C E\left(\mathrm{~N}_{2} \mathrm{O}\right)
$$

The yield scaled GWP was calculated according to Shang et al. (2011).

$$
\text { Yield-scaled GWP }=\text { GWP/Y }
$$

Where, $\mathrm{Y}$ is the crop grain yield for the gas sampling season. Data of radiation and temperature use efficiencies, including radiation production efficiency (RPE), radiation use efficiency (RUE), accumulative temperature production efficiency (ATPE) and accumulative temperature use efficiency (ATUE) of $\geqslant 10^{\circ} \mathrm{C}$ were calculated by Chang et al. (2016).

$$
\begin{aligned}
& \operatorname{RPE}\left(\mathrm{g} \mathrm{MJ}^{-1}\right)=\text { grain yield/solar radiation } \\
& \text { RUE }(\%)=\text { primary productivity/solar radiation }
\end{aligned}
$$

$\operatorname{ATPE}\left(\mathrm{kg} \mathrm{hm}^{-2}{ }^{\circ} \mathrm{C}^{-1} \mathrm{~d}^{-1}\right)=$ grain yield/accumulative temperature (7)

ATUE $(\%)=$ accumulative temperature during crop season / annual accumulative temperature

\section{Statistical analysis}

Data were analyzed by using the PROC ANOVA procedure in S.A.S. version 9.3 (S.A.S. Institute Inc., Cary, NC, USA). Means of rice yield, cumulative GHG emissions, GWP, yield-scaled GWP, crop yield and resources utilization efficiency were compared based on the least significant difference (LSD) test at the 0.05 probability level.

\section{Results}

\section{Yield performance}

Across the 2-year observation, no significant difference was detected for grain yield and above-ground biomass in the rice season between rice-fallow and rotation systems of ricewheat or rice-rape (Fig. 1a, b). In spite of longer growing seasons for the winter crops, their grain yields were much smaller than those of rice (Fig. 1a). Wheat showed significant higher $(P \leqslant 0.05)$ grain yields than rape in paddy rotation systems in both years (Fig. 1a). When it came to the annual total grain yield, rice-wheat and rice-rape rotations had greater values than rice-fallow in both years. As shown in Fig. 1b, rice-wheat had the highest annual above-ground biomass because of a higher residue production from winter crops.

\section{Solar radiation and heat efficiency}

Indicators such as radiation production efficiency (RPE), radiation use efficiency (RUE), accumulative temperature production efficiency (ATPE) and accumulative temperature use efficiency (ATUE) of $\geqslant 10^{\circ} \mathrm{C}$ were successfully used for solar radiation and heat resources utilization comparisons among different farming systems. In this study, no significant difference was observed for RPE and ATPE during the rice season (Table 1). In the winter season, RPE and ATPE values were zero for rice-fallow because no crop was planted or harvested during winter seasons. For rice-wheat and rice-rape, wheat showed greater $(P \leqslant 0.05)$ RPE and ATPE values than rape (Table 1$)$, mainly due to the higher grain yields and dry matter accumulation in rice-wheat plots (Fig. 1). The lower values for RPE and ATPE in the winter seasons could be attributed to the lower temperature in wheat and rape growing seasons. When compared with rice-fallow, the annual RPE and ATPE were significantly increased $(P \leq 0.05)$ by rice-wheat and by rice-rape in both years (Table 1$)$. By calculation based on above ground dry matter accumulation, RUE values ranged from $0.80-1.68 \%$ (Table 1 ). The highest RUE values were observed in rice-wheat rotation plots, followed by rice-rape and rice-fallow. No significant diffidence was shown for RUE between rice-rape and rice-fallow in 20182019. Both the rotation treatments improved ATUE values significantly $(P \leq 0.05)$ than rice-fallow. Rice-wheat and rice-rape plots had similar ATUE values because of the same growing stages for the winter seasons.

\section{The $\mathrm{CH}_{4}$ and $\mathrm{N}_{2} \mathrm{O}$ fluxes and GWP}

According to the two-year observation, $\mathrm{CH}_{4}$ emission rates ranged respectively from $0.05 \mathrm{mg} \mathrm{m}^{-2} \mathrm{~h}^{-1}$ to $21.52 \mathrm{mg}$ $\mathrm{m}^{-2} \mathrm{~h}^{-1}$ for the rice seasons and from $0 \mathrm{mg} \mathrm{m}^{-2} \mathrm{~h}^{-1}$ to $1.98 \mathrm{mg}$ $\mathrm{m}^{-2} \mathrm{~h}^{-1}$ for the winter seasons (Fig. 2a). The three treatments showed a similar $\mathrm{CH}_{4}$ emission trend during the rice seasons. 
Songling et al. / Intl J Agric Biol, Vol 25, No 6, 2021

Table 1: The 2-year (2017-2019) radiation and temperature production efficiency and use efficiency of different cropping patterns

\begin{tabular}{|c|c|c|c|c|c|c|c|c|c|}
\hline \multirow[t]{2}{*}{ Year } & \multirow[t]{2}{*}{ Treatment } & \multicolumn{3}{|c|}{$\operatorname{RPE}\left(\mathrm{g} \mathrm{MJ}^{-1}\right)$} & \multirow[t]{2}{*}{ RUE (\%) } & \multicolumn{3}{|c|}{ ATPE $\left(\mathrm{kg} \mathrm{hm}^{-2 \circ} \mathrm{C}^{-1} \mathrm{~d}^{-1}\right)$} & \multirow[t]{2}{*}{ ATUE $(\%)$} \\
\hline & & Rice season & Winter season & Annual & & Rice season & Winter season & Annual & \\
\hline \multicolumn{10}{|l|}{$2017-2018$} \\
\hline & $\mathrm{RF}$ & $0.51 \pm 0.02 \mathrm{a}$ & $0 \mathrm{c}$ & $0.26 \pm 0.01 b$ & $0.91 \mathrm{c}$ & $5.17 \pm 0.3 \mathrm{a}$ & $0 \mathrm{c}$ & $3.70 \pm 0.18 b$ & $71.63 \mathrm{~b}$ \\
\hline & RR & $0.52 \pm 0.01 \mathrm{a}$ & $0.16 \pm 0.00 \mathrm{~b}$ & $0.35 \pm 0.00 \mathrm{a}$ & $1.23 \mathrm{~b}$ & $5.24 \pm 0.1 \mathrm{a}$ & $4.68 \pm 0.61 b$ & $5.15 \pm 0.05 \mathrm{a}$ & $93.88 \mathrm{a}$ \\
\hline & RW & $0.52 \pm 0.01 \mathrm{a}$ & $0.26 \pm 0.03 \mathrm{a}$ & $0.40 \pm 0.01 \mathrm{a}$ & $1.68 \mathrm{a}$ & $5.25 \pm 0.1 \mathrm{a}$ & $7.71 \pm 0.77 \mathrm{a}$ & $5.74 \pm 0.16 \mathrm{a}$ & $95.23 \mathrm{a}$ \\
\hline & $\mathrm{RF}$ & $0.45 \pm 0.02 \mathrm{a}$ & $0 \mathrm{c}$ & $0.24 \pm 0.02 b$ & $0.80 \mathrm{~b}$ & $4.4 \pm 0.2 \mathrm{a}$ & $0 \mathrm{c}$ & $3.18 \pm 0.17 b$ & $72.87 \mathrm{~b}$ \\
\hline & RW & $0.47 \pm 0.02 \mathrm{a}$ & $0.25 \pm 0.03 \mathrm{a}$ & $0.37 \pm 0.01 \mathrm{a}$ & $1.48 \mathrm{a}$ & $4.65 \pm 0.2 \mathrm{a}$ & $7.57 \pm 0.66 \mathrm{a}$ & $5.32 \pm 0.16 \mathrm{a}$ & $92.01 \mathrm{a}$ \\
\hline
\end{tabular}

Mean \pm standard deviation. Different lower-case letters indicate the significantly differences $(P<0.05)$ based on LSD multiple range tests. RF represents rice-fallow, RR represents rice-rape, RW represents rice-wheat. RPE represents radiation production efficiency, RUE represents radiation use efficiency, ATPE represents accumulative temperature production efficiency of $\geq 10^{\circ} \mathrm{C}$, ATUE represents accumulative temperature use efficiency of $\geq 10^{\circ} \mathrm{C}$

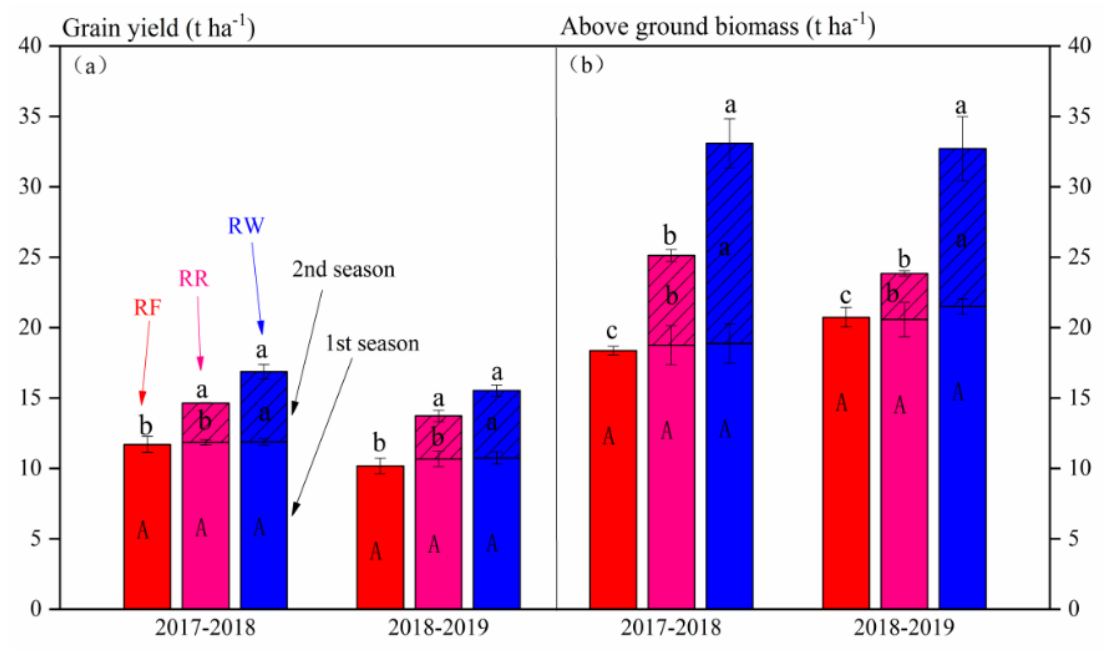

Fig. 1: Correlation between the average crop grain yield (a) and above ground biomass (b). RF represents rice-fallow, RR represents rice-rape, RW represents rice-wheat. The Correlation shows positive correlation between grain yield and above ground biomass

Two major peaks were detected for $\mathrm{CH}_{4}$ emission for all the treatments in rice seasons both in 2017 and in 2018. $\mathrm{CH}_{4}$ emission rates rose steadily after rice transplanting at early June and got its first peak at late June when rice plants were at full tillering stage. Thereafter, $\mathrm{CH}_{4}$ emission decreased sharply nearly to zero in the mid-season drainage. $\mathrm{CH}_{4}$ emission started to increase again when the field was flooded with water and got the second peak at middle August when rice plants were at flowering stage. Little $\mathrm{CH}_{4}$ emission was observed for the three treatments during the winter crop growing seasons (Fig. 2a). $\mathrm{CH}_{4}$ fluxes were calculated for the rice season, the winter season and the annual level, respectively. As shown in Table 2, the twoyear average values for $\mathrm{CH}_{4}$ flux in the rice season was increased by $42.0 \%$ by rice-wheat but was decreased by $35.6 \%$ by rice-rape when compared with rice-fallow. For the annual level, $\mathrm{CH}_{4}$ flux was promoted by $40.9 \%$ by ricewheat and declined by $35.5 \%$ by rice-rape.

$\mathrm{N}_{2} \mathrm{O}$ emission rates ranged respectively from 0 to $420.7 \mu \mathrm{g} \mathrm{m}^{-2} \mathrm{~h}^{-1}$ for the rice seasons and from 0 to 169.5 $\mu \mathrm{g} \mathrm{m}^{-2} \mathrm{~h}^{-1}$ for the winter seasons (Fig. 2b). In general, $\mathrm{N}_{2} \mathrm{O}$ rates were greater in the rice seasons than in the winter seasons in the two-year observation. Dramatically different
$\mathrm{N}_{2} \mathrm{O}$ emission patterns were measured among treatments and years. In the rice seasons and the beginning of the winter season in 2017 , most of the $\mathrm{N}_{2} \mathrm{O}$ rates were higher than $100 \mu \mathrm{g} \mathrm{m}^{-2} \mathrm{~h}^{-1}$ for rice-wheat plots. For the year 2018, the rice season's $\mathrm{N}_{2} \mathrm{O}$ rates showed an impulse trend regardless of the treatments. $\mathrm{N}_{2} \mathrm{O}$ emission peaks were obviously higher in 2018 than those in 2017 (Fig. 2b). When compared with rice-fallow, $\mathrm{N}_{2} \mathrm{O}$ seasonal flux in the rice season was increased by 54.2 and $8.3 \%$ in rice-wheat and rice-rape plots, respectively. For the annual level, $\mathrm{N}_{2} \mathrm{O}$ emission was promoted by 66.7 and $26.3 \%$ in rice-wheat and rice-rape plots, respectively (Table 2).

Global warming potential (GWP) was calculated based on the data for $\mathrm{CH}_{4}$ and $\mathrm{N}_{2} \mathrm{O}$ annual emissions to make an integrated estimation of the global warming effects of the greenhouse gases emitted from the field. In this study, GWP values of $\mathrm{CH}_{4}$ and $\mathrm{N}_{2} \mathrm{O}$ were highest in rice-wheat treatment and lowest in rice-rape treatment during both years (Table 2). The increased GWP could be a result of a greater annual $\mathrm{CH}_{4}$ emission as $\mathrm{CH}_{4}$ emission contributed the most part of GWP. We also estimated yield-scaled GWP which was calculated as GWP divided by grain yield. As shown in Table 2, yield-scaled GWP of rice-rape was the 
Table 2: The 2-year (from 2017-2019) average grain yield, $\mathrm{CH}_{4}$ and $\mathrm{N}_{2} \mathrm{O}$ emissions, global warming potentials (GWP) and yield-scaled GWP by different planting patterns

\begin{tabular}{|c|c|c|c|c|c|c|c|c|}
\hline \multirow[t]{2}{*}{ Year } & \multirow[t]{2}{*}{ Treatment } & \multicolumn{3}{|c|}{$\mathrm{CH}_{4}$ emission $\left(\mathrm{kg} \mathrm{ha}^{-1}\right)$} & \multicolumn{2}{|c|}{$\mathrm{N}_{2} \mathrm{O}$ emission $\left(\mathrm{kg} \mathrm{ha}^{-1}\right)$} & \multirow{2}{*}{$\begin{array}{l}\mathrm{GWP}\left(\mathrm{kg} \mathrm{CO}_{2^{-}}\right. \\
\left.\text {equivalens ha }{ }^{-1}\right)\end{array}$} & \multirow{2}{*}{$\begin{array}{l}\text { Yield-scaled } \mathrm{GWP}\left(\mathrm{kgCO}_{2}-\right. \\
\text { equivales per kg grain })\end{array}$} \\
\hline & & Rice season & Winter season & Annual & Rice season & Winter season & & \\
\hline \multicolumn{9}{|c|}{$2017-2018$} \\
\hline & $\mathrm{RF}$ & $135.3 \pm 19.3 \mathrm{a}$ & $5.7 \pm 1.3 \mathrm{~b}$ & $141.0 \pm 18.9 \mathrm{~b}$ & $0.9 \pm 0.4 \mathrm{~b}$ & $0.6 \pm 0.4 b$ & $1.5 \pm 0.9$ b $3979.9 \pm 717.8 b$ & $0.34 \pm 0.1 \mathrm{a}$ \\
\hline & RR & $86.4 \pm 16.4 \mathrm{~b}$ & $5.9 \pm 1.5 \mathrm{~b}$ & $92.4 \pm 20.3 \mathrm{c}$ & $1.3 \pm 0.6 b$ & $1.3 \pm 0.2 \mathrm{a}$ & $2.6 \pm 0.4$ b $3074.0 \pm 457.6 \mathrm{~b}$ & $0.21 \pm 0.1 b$ \\
\hline & RW & $169.9 \pm 16.1 \mathrm{a}$ & $13.0 \pm 3.5 \mathrm{a}$ & $182.1 \pm 25.4 \mathrm{a}$ & $2.9 \pm 1.1 \mathrm{a}$ & $1.4 \pm 0.1 \mathrm{a}$ & $4.4 \pm 0.9$ a $5848.7 \pm 377.0$ a & $0.35 \pm 0.1 \mathrm{a}$ \\
\hline \multicolumn{9}{|c|}{ 2018-2019 } \\
\hline & $\mathrm{RF}$ & $100.4 \pm 13.1 \mathrm{~b}$ & $12.8 \pm 2.2 \mathrm{a}$ & $113.2 \pm 17.5 b$ & $3.9 \pm 0.5 b$ & $0.4 \pm 0.2 b$ & $4.2 \pm 2.8$ a $4092.5 \pm 1267.9 b$ & $0.40 \pm 0.2 \mathrm{a}$ \\
\hline & RR & $65.5 \pm 15.5 \mathrm{c}$ & $6.1 \pm 2.0 \mathrm{~b}$ & $71.6 \pm 23.3 \mathrm{c}$ & $3.9 \pm 0.4 \mathrm{~b}$ & $0.8 \pm 0.3 \mathrm{a}$ & $4.6 \pm 0.3$ a $3168.6 \pm 514.2 \mathrm{~b}$ & $0.23 \pm 0.1 b$ \\
\hline & RW & $164.7 \pm 11.2 \mathrm{a}$ & $11.4 \pm 3.8 \mathrm{a}$ & $176.1 \pm 22.4 \mathrm{a}$ & $4.5 \pm 0.5 \mathrm{a}$ & $0.6 \pm 0.1 \mathrm{ab}$ & $5.1 \pm 2.0$ a $5933.5 \pm 697.8$ a & $0.38 \pm 0.1 \mathrm{a}$ \\
\hline
\end{tabular}
rice-rape, RW represents rice-wheat

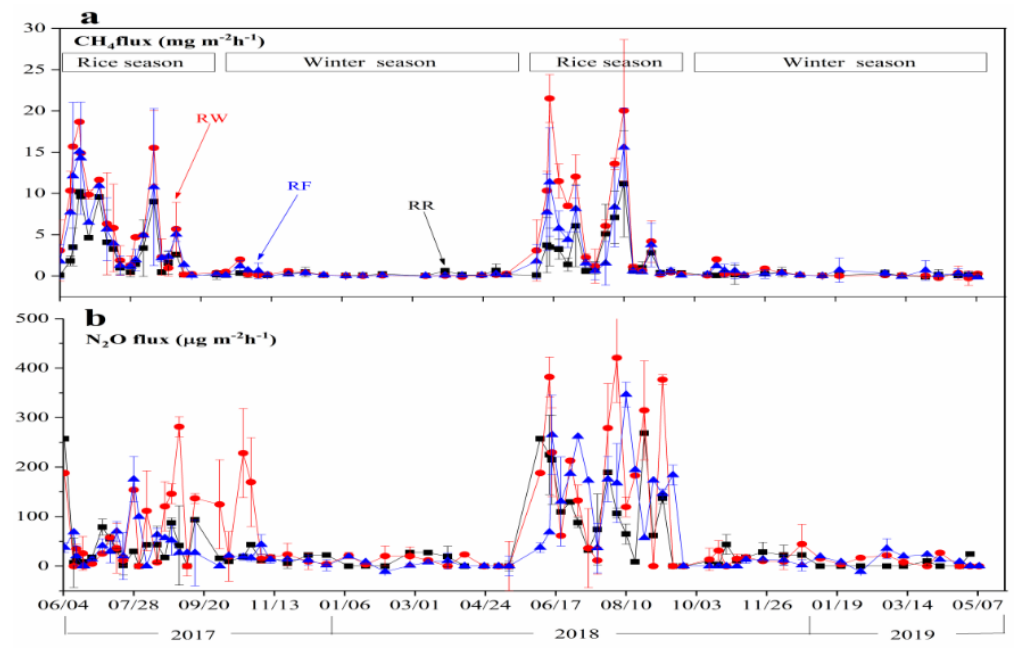

Fig. 2: Seasonal variations in $\mathrm{CH}_{4}$ fluxes (a) and $\mathrm{N}_{2} \mathrm{O}$ fluxes (b) during the rice and winter growing seasons from 2017 to 2019 . $\mathrm{RF}$ represents rice-fallow, RR represents rice-rape, RW represents rice-wheat. The data shown in the panel are averages of the three represent for individual treatment. Vertical bars represent the standard errors of the three replicates

lowest while no significant difference was found between rice-wheat and rice-fallow.

\section{Discussion}

Although rotation with rape or with wheat showed no effect on radiation and heat use efficiencies during the rice season; however, rotation prompted the radiation and heat use efficiencies from the perspective of annual production. Moreover, the $\mathrm{CH}_{4}$ and $\mathrm{N}_{2} \mathrm{O}$ emissions from paddy soils differed with rotation with different winter crops (Table 2).

There were diverse reports on the effects of rotation on the main cereal crop yields when the same rotation pattern was applied continuously over years. Crops followed by legume rotations usually showed promoted nitrogen accumulation and higher grain yields (Yu et al. 2014; Zhu et al. 2016). Sometimes, yield reduction of the main crop resulted from rotation could be attributed to the competition for nitrogen after the incorporation of the second crop residue, such as rape and ryegrass because of a high carbon/nitrogen ratio (Armstrong et al. 1996; Nie et al.
2019), in spite that the rotation treatments were coupled with crop residue return, which means an additional nitrogen supply during the main rice crop season (Zhu et al. 2016). In this study, rotation with wheat or with rape had no significant effect on the grain yield and above ground biomass of rice for both years, possibly due to the high level of rice grain yields (ranged from 12.1 to $13.6 \mathrm{t} \mathrm{ha}^{-1}$, Fig. 1a). However, rotation prompted crops production from the perspective of annual production.

Rotation might change climate resources utilization such as light and heat in two ways. First, when compared with fallow, rotation with winter crops could utilize the light and heat resources which would otherwise be wasted in the winter season (Chen et al. 2021). Second, the management of the winter crops might affect the growth of the following main summer crop (Huang et al. 2006). In this study, rotation systems are more productive than rice-fallow, mostly due to the winter crops utilization on light and temperature resources. The annual yield and biomass advantages of rice-wheat and rice-rape were mainly resulted from the significantly increased radiation and temperature 
use efficiency (Table 1). Because of no difference was found for rice grain yields, the yield based light and heat utilization indices such as radiation production efficiency and accumulative temperature production efficiency in the rice seasons were not significantly affected by rotation in this study. When it comes to the winter season, wheat had a greater potential than rape in improving light and temperature resources.

$\mathrm{CH}_{4}$ and $\mathrm{N}_{2} \mathrm{O}$ emissions are closely related to farming system changes including crop species, fertilizer application, water management and straw returning in paddy fields (Yao et al. 2017; Sumaira et al. 2019; Zhao et al. 2020). The $\mathrm{CH}_{4}$ emission peaks observed in this study were similar with those measured in other studies based on cropping system management (Zhang et al. 2015; Xu et al. 2016), when the paddy soil was flooded and the rice plants were at a rapid growing stage. Winter rotation coupled with winter crops straw incorporation didn't change the $\mathrm{CH}_{4}$ emission trend during the rice season. However, the seasonal $\mathrm{CH}_{4}$ emission flux was dramatically different among different winter rotations when compared with fallow. The increased $\mathrm{CH}_{4}$ emission for rice-wheat ranged $26.5-64.0 \%$ for the rice season and $29.1-55.6 \%$ for the whole year, respectively. The promoted $\mathrm{CH}_{4}$ emission could be attributed to the enhanced above ground biomass yield of wheat and a larger quantity of straw returning into the soil after wheat harvest (Ma et al. 2009). Organic material incorporation, especially those with a high $\mathrm{C} / \mathrm{N}$ ratio, provided available carbon substrate for $\mathrm{CH}_{4}$ production methanogens.

Similar with $\mathrm{CH}_{4}$ emission, $\mathrm{N}_{2} \mathrm{O}$ emission flux was smaller in the winter seasons than in the rice seasons, possibly due to the lower temperature. $\mathrm{N}_{2} \mathrm{O}$ production and emission from paddy soils are mainly happened during the processes of nitrification and denitrification (Wang et al. 2016). Crop rotations associated with different organic carbon and nitrogen management could change the substrate availability and the activity of functional microorganisms. Rice-wheat increased $\mathrm{N}_{2} \mathrm{O}$ emission in the rice seasons while no significant difference for rice-rape and rice-fallow. The reason could be explained by the difference in the quality and quantity of straw returning into the soil followed by different winter crops.

Global warming potential could be a useful indicator to investigate integrative effects of different greenhouse gases from agricultural systems. The relationship of food production and greenhouse gases emission could be further measured by introducing the yield-scaled GWP. In spite that the global warming potential of $\mathrm{N}_{2} \mathrm{O}$ is approximately 12 times larger than that of $\mathrm{CH}_{4}$, the average $\mathrm{CH}_{4}$ emissions was nearly 35 times that of $\mathrm{N}_{2} \mathrm{O}$, resulting in the major contribution for GWP from $\mathrm{CH}_{4}$ emission (Table 2). Because of a significant increase of $\mathrm{CH}_{4}$ emission, the GWP values were highest in rice-wheat, followed by rice-fallow and rice-rape. The yield-scaled GWP was decreased by ricerape because of its lower $\mathrm{CH}_{4}$ emission.

\section{Conclusion}

Annual grain yield, radiation and heat resources utilization and their production efficiency were improved by rotation with winter crops. The $\mathrm{CH}_{4}$ emission from paddy soils as well as yield-scaled GWP was increased by rice-wheat and decreased by rice-rape system. These results suggested ricerape could be more sustainable cropping pattern to increase solar radiation and heat resources utilization and mitigate greenhouse gases emission.

\section{Acknowledgements}

This work was supported by the National Key Program of Research \& Development of China (2017YFD0301400), National Natural Science Foundation of China (No. 31870424), Hubei Key Program of Research and Development (No. 2020BBA044, 2020BBB089).

\section{Author Contributions}

Gong Songling: Initial draft and data analysis; Li Chengwei: Data collection; Liu Zhangyong: Data analysis method; Zhu Bo: Framework and overall idea of the paper.

\section{Conflicts of Interest}

The authors declare there is no conflict of interest regarding the publication of this paper.

\section{Data Availability}

The data will be available upon reasonable request to the corresponding author.

\section{Ethics Approval}

Not applicable.

\section{References}

Armstrong EL, DP Heenan, JS Pate, MJ Unkovich (1996). Nitrogen benefits of lupins, field pea, and chickpea to wheat production in south-eastern Australia. Crop Past Sci 48:39-48

Chang Q, J Wang, WD Yu, N Wang, MX Tan (2016). Tempo-spatial characteristics and impact factors of radiation use efficiency of wheat-maize rotation system in Henan Province. Chin $J$ Agrometeorol 37:316-325

Chen ZK, P Li, SS Jiang, HY Chen, JP Wang, CG Cao (2021). Evaluation of resource and energy utilization, environmental and economic benefits of rice water-saving irrigation technologies in a rice-wheat rotation system. Sci Total Environ 24; Article 143748

Chang Q, J Wang, WD Yu, N Wang, MX Tan (2016). Tempo-spatial characteristics and impact factors of radiation use efficiency of wheat-maize rotation system in Henan Province. Chin $J$ Agrometeorol 37:316-325

Congreves KA, DC Hooker, A Hayes A, EA Verhallen, LLV Eerd (2017). Interaction of long-term nitrogen fertilizer application, crop rotation, and tillage system on soil carbon and nitrogen dynamics. Plant Soil 410:113-127 


\section{Rice-rape Rotation Reduced GHG Emissions / Intl J Agric Biol, Vol 25, No 6, 2021}

Du X, L Kong, M Xi, W Wu, J Chen, W Yue (2019). Characteristics of resource allocation and utilization of rice-wheat double cropping system in the Jianghuai area. Chin J Ecol Agric 27:1078-1087

FAO - Food and Agriculture Organization statistical database (2019). Agricultural data available @ http://faostat3.fao.org

Huang GQ, YM Xiong, HY Qian, SB Wang, LW Liu, QG Zhao (2006). Ecological analysis on crop rotation systems of paddy field. Acta Ecol Sin 26:1159-1164

IPCC (2007). Climate Change 2007: The Physical Science Basis Contribution of Working Group I to the Fourth Assessment Report of the IPCC, p:104. Cambridge University Press, New York, USA

Jia Q, R Xu, S Chang, C Zhang, Y Liu,W Shi, Z Peng, F Hou (2020). Planting practices with nutrient strategies to improves productivity of rainfed corn and resource use efficiency in semi-arid regions. Agric Water Manage 228; Article 105879

Kamp T, H Steindl, JC Munch (2001). Monitoring trace gas fluxes $\left(\mathrm{N}_{2} \mathrm{O}\right.$, $\mathrm{CH}_{4}$ ) from different soils under the same climatic conditions and the same agricultural management. Phyton 41:119-130

Liu XJ, FS Zhang (2011). Nitrogen fertilizer induced greenhouse gas emissions in China. Curr Opin Environ Sustain 5:407-413

Ma J, E Ma, H Xu, K Yagi, ZC Cai (2009). Wheat straw management affects $\mathrm{CH}_{4}$ and $\mathrm{N}_{2} \mathrm{O}$ emission from rice fields, Soil Biol Biochem 41:1023-1028

Machado PVF, RE Farrell, W Deen, RP Voroney, C Wagner-Riddle (2021). Contribution of crop residue, soil, and fertilizer nitrogen to nitrous oxide emissions varies with long-term crop rotation and tillage. Sci Total Environ 767:145107

Mer JL, P Roger (2001) Production, oxidation, emission and consumption of methane by soils: A review. Eur J Soil Biol 37:25-50

Mosier AR, AD Halvorson, CA Reule, XJ Liu (2006). Net global warming potential and greenhouse gas intensity in irrigated cropping systems in northeastern Colorado. J Environ Qual 35:1584-1598

Nie J, L Yi, H Xu, Z Liu, Z Zeng, D Paul, WK George, AH Bruce, B Zhu (2019). Legumious cover crop Astragalus sinicus enhances grain yields and nitrogen use efficiency through increased tillering in an intensive double-cropping rice system in southern China. Agronomy 9; Article 554

Shang QY, XX Yang, CM Gao, PP Wu, JJ Liu, YC Xu, QR Shen, JW Zou, SW Guo (2011). Net annual global warming potential and greenhouse gas intensity in Chinese double rice-cropping systems: A 3 -year field measurement in long-term fertilizer experiments. Glob Change Biol 17:2196-2210

Smith P, D Martino, ZCai, D Gwary, HH Janzen, P Kuma, B McCarl, S Ogle, FO'Mara, C Rice, RJ Scholes, O Sirotenko, M Howden, T McAllister, G Pan, V Romanenkov, S Rose, U Schneider, S Towprayoon (2007). Climate change 2007: Mitigation of climate change: contribution of Working Group III to the Fourth Assessment Report of the Intergovernmental Panel on Climate Change, Vol. 45, pp:497-540. Cambridge University Press, Cambridge, UK and New York, USA
Sumaira H, T Jin, ZY Liu, B Zhu, JW Nie, J Zhu (2019). Effects of land use conversion from upland to paddy field on ammonia-oxidizing archaeal and ammonia-oxidizing bacterial communities in Jianghan plain, Hubei Province, China. Intl J Agric Biol 21:421-428

Sun LY, YC Ma, B Li, C Xiao, LX Fan, ZQ Xiong (2018). Nitrogen fertilizer in combination with an ameliorant mitigated yield-scaled greenhouse gas emissions from a coastal saline rice field in southeastern China. Environ Sci Pollut Res 25:15896-15908

Taveira CJ, RE Farrell, C Wagner-Riddle, PVF Machado, KA Congreves (2020). Tracing crop residue $\mathrm{N}$ into subsequent crops: Insight from long-term crop rotations that vary in diversity. Field Crop Res 255:107904

Tellez-Rio A, A Vallejo, S García-Marco, D Martin-Lammerding, JL Tenorio, RM Rees, G Guardia (2017). Conservation agriculture practices reduce the global warming potential of rainfed low $\mathrm{N}$ input semi-arid agriculture. Eur J Agron 84:95-104

Wang ML, RG Hu, JS Zhao, Y Kuzyakov, SR Liu (2016). Iron oxidation affects nitrous oxide emission via donating electrons to denitrification in paddy soils. Geoderma 271:174-180

Xu Y, M Zhan, CG Cao, SY Tian, JZ Ge, SY Li, MY Wang, GY Yuan (2016). Improved water management to reduce greenhouse gas emissions in no-till rapeseed-rice rotations in Central China. Agric Ecosyst Environ 221:87-98

Yao Z, G Yan, X Zheng, R Wang, C Liu, K Butterbach-Bahl (2017). Straw return reduces yield-scaled $\mathrm{N}_{2} \mathrm{O}$ plus $\mathrm{NO}$ emissions from annual winter wheat-based cropping systems in the North China Plain. Sci Environ 509:174-185

Yu Y, L Xue, Y Yang (2014). Winter legumes in rice crop rotations reduces nitrogen loss, and improves rice yield and soil nitrogen supply. Agron Sustain Dev 34:633-640

Zhang T, Y Huang, X Yang (2013). Climate warming over the past three decades has shortened rice growth duration in China and cultivar shifts have further accelerated the process for late rice. Glob Change Biol 19:563-570

Zhang ZS, LJ Guo, TQ Liu, CF Li, CG Cao (2015). Effects of tillage practices and straw returning methods on greenhouse gas emission and net ecosystem economic budget in rice-wheat cropping systems in central china. Atmos Environ 122:636-644

Zhao YH, XB Wang, XB Zha, CY Feng, JG Yu, JG Jiao, X Xiao (2020). Effects of plow tillage and different water and fertilizer management methods on the soil properties and rice yields of paddy under wheat straw returning. J Agric Res Environ 37:195-201

Zhou YL, B Sun (2017). Nitrogen use efficiency of rice under cadmium contamination: Influence of rice cultivar versus soil type. Pedosphere 27:1092-1104

Zhu B, L Yi, H Xu, L Guo, Y Hu, Z Zeng, F Chen, Z Liu (2016). Nonleguminous cover crop and nitrogen rate in relation to double rice grain yield and nitrogen uptake in Dongting Lake Plain, Hunan, China. J Integr Agric 15:2507-2514 